\title{
ХАРАТЕРИСТИКА РОСЛИН РОДУ МИКОЛАЙЧИКИ ТА ПЕРСПЕКТИВИ ЇХ ВИКОРИСТАННЯ У МЕДИЦИНІ
}

\section{CHARACTERISTICS OF PLANTS OF THE GENUS ERYNGIUM AND PROSPECTS OF THEIR USE IN MEDICINE}

Андрій Грицик (Andrii Grytsyk) ${ }^{1}$, Ксенія Гнатойко (Kseniia Gnatoyko) ${ }^{1}$

1 Івано-Франківський національний медичний університет, Івано-Франківськ, Україна (IvanoFrankivsk National Medical University, IvanoFrankivsk, Ukraine)

*Corresponding author: Kseniia Gnatoyko, affiliated to Ivano-Frankivsk National Medical University, IvanoFrankivsk, Ukraine
Received: October 25, 2021

Published: November 01, 2021
Abstract. The study was dedicated to carrying out a complete analysis of modern literature on botanical characteristics, chemical composition, distribution and use in medicine of plants of genus Eryngium. The methods of patent information search and data analysis of modern literature were used in the work. Conducted a morphological study of species of the genus Eryngium. According to the database "The Plant list", the genus Eryngium includes 257 recognized species, which are distributed in Eurasia, North and South America, Africa and Australia. Eryngium are usually wild plants, but they are successfully cultivated in many countries. The genus Eryngium includes one-, two-, and perennial grasses, the height of which is from $40 \mathrm{~cm}$ to $1.5 \mathrm{~m}$, depending on the species. Stem in Eryngium straight, branched at the top; flowers small, mostly blue; fruits are covered with scales. On the territory of Ukraine, Eryngium planum L., Erynguim campestre L., Eryngium maritimum L. are widespread. Some species of Eryngium are eaten and used as an ornamental plant in floristics. Plants of the genus Eryngium contain a variety of biologically active substances that have a pharmacological effect on the human body, so in folk medicine, Eryngium has long been used as an antispasmodic, diaphoretic, diuretic, expectorant. Species of the genus Eryngium are one-, two-, and perennial herbs of the Apiaceae family, which are widespread throughout the globe. Eryngium has long been used in folk medicine, but is not an official raw material, although the chemical composition of Eryngium is able to have a positive pharmacological effect on the human body. Seed and raw material productivity of the Eryngium is sufficient for industrial cultivation. Eryngium are promising medicinal plants, and need further study to be able to create new drugs.

Keywords: eryngium, apiaceae, medicinal plants, biologically active substances.

Вступ. На сучасному етапі розвитку фармацевтичної науки все більше уваги приділяється лікарським препаратам з рослинної сировини. Фітозасоби, 
нормалізуючи функції окремих органів і систем, позитивно впливають на обмін речовин в організмі. Лікарські рослини та одержані з них біологічно активні речовини виявляють широкий спектр фармакологічної дії, що сприяє ефективному лікуванню захворювань.

Перевага лікарських рослин у тому, що вони, на відміну від синтетичних лікарських препаратів, рідко викликають ускладнення, побічні дії, алергічні реакції; їх можна призначати для тривалого застосування. На сьогодні рослини роду Миколайчики не використовують в офіційній медицині, але вони широко поширені на території України та вміщують різні групи біологічно активних речовин, які здатні чинити терапевтичний ефект на організм людини. Тому миколайчики $є$ перспективними для фармакогностичного дослідження.

Мета. Морфологічний аналіз деяких видів роду Миколайчики. Аналіз сучасної літератури щодо ботанічної характеристики, хімічного складу, розповсюдження та використання в медицині рослин роду Миколайчики.

Матеріали та методи дослідження. Проведено морфологічний аналіз та описано діагностичні ознаки деяких видів роду Миколайчики. Використано методи інформаційного пошуку та аналізу даних літератури щодо хімічного складу, фармакологічних властивостей та використання в медицині рослин роду Миколайчики.

Результати дослідження та їх обговорення. Рослини роду Миколайчики (Eryngium) родини Зонтичні (Apiaceae) - це багато-, рідше дво- або однорічні трави.

Згідно із базою даних Королівського ботанічного саду К'ю та Міссурійського ботанічного саду «The Plant list» до роду Миколайчики відносяться 257 визнаних видів, поширених в теплих і помірних широтах обох півкуль [1-3].

Більшість видів є дикорослими, природним ареалом для них є Північна та Південна Америка, Європа, Південно-Західна та Центральна Азія, Австралія, Північна Африка [4].

Деякі види культивують в Північній Америці, Центральній Африці та Південній Азії (Рис.1).

Види роду Миколайчики, які зростають в Україні, належать до середземноморських видів.

На території України зростають м. плоскі (Eryngium planum L.), м. польові (Erynguim campestre L.), м. приморські (Eryngium maritimum L.) [4].

Миколайчики плоскі (Eryngium planum L.) - багаторічна гола рослина висотою 30-80 см. Стебло у миколайчиків плоских ребристе, у верхній частині розгалужене, синюватого кольору. Покривна тканина стебла - епідерма, трихоми відсутні. Ендодерма слабо виражена. Провідна система пучкового типу. Пучки відкриті колатеральні, розміщуються по зовнішньому кругу. Ксилема в декілька раз перевищує об'єм флоеми [5-7].

Листя в прикореневій розетці цільні, овальної форми з серцеподібною основою, довжиною до $32 \mathrm{~cm}$, шириною 6-10 см. Черешок листа завдовжки 1219 см, шириною 4-7 мм. Нижні стеблові листя цільні, черешкові, довжиною до 15-17 см, шириною до 5-7 см. Черешок довжиною до 5-7 см, шириною 5-6 мм. 
Верхні стеблові листки сидячі, пальчатолопастні або пальчастороздільні, довжиною до 6-9 см, шириною до 7-9 см. Крайові приквіткові листя вузькі, лінійні, менш довгі, в кількості 6 шт. Довжина їх 1,5-2,0 см, ширина 2,0-2,5 мм. Черешкові листки дорховентрального типу. Епідерма без трихом. Клітини мезофілу овальної форми, розташовуються в декілька шарів, містять велику кількість хлоропластів. Механічна тканина представлена коленхімою.

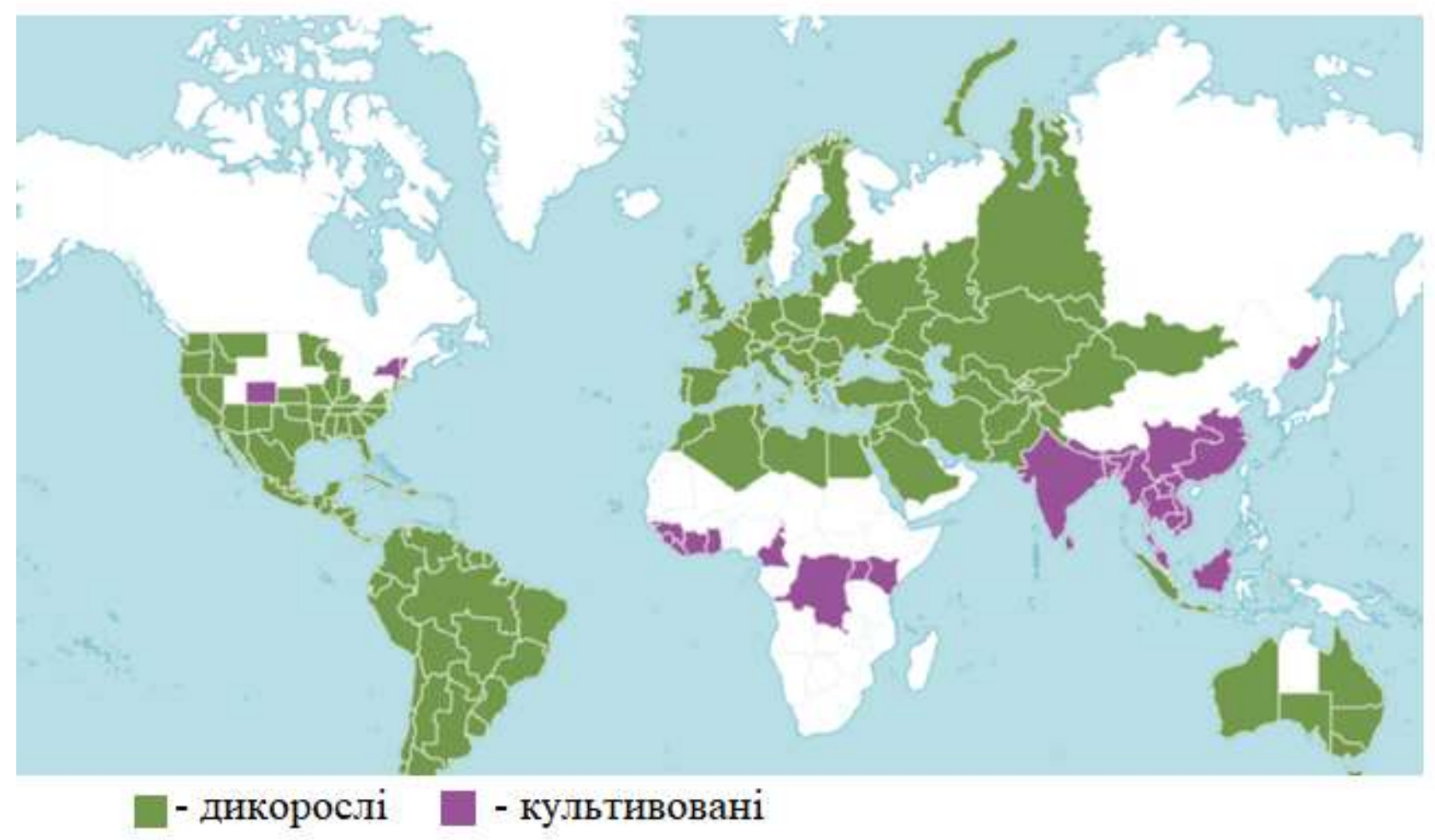

Рис.1. Ареали зростання видів роду Миколайчики.

Корінь миколайчиків плоских світло-коричневого кольору, довжиною 15$30 \mathrm{~cm}$, товщиною - 1,3-2,5 см, округлий на поперечному зрізі. В області флоеми і перициклу виявлені ефірноолійні канальці округлої або овальної форми, розміри на поперечному зрізі в середньому складають $41,6 \times 20,8$ мкм.

Пелюстки голубі. Плід в миколайчиків плоских - двосім'янка вкрита лусочками [5-7].

Період цвітіння: червень-вересень. Росте на більшій частині України, крім Карпат, по заплавних луках, по степах, перелогах, пісках, біля автомобільних шляхів.

Миколайчики польові (Eryngium campestre L.) - багаторічна колюча рослина. Стебло заввишки до $60 \mathrm{~cm}$, розгалужене, сірувато-зеленого кольору. Нижні листки черешкові, жорсткошкірясті. Верхні листки сидячі, трійчасті, 3 глибокоперистороздільні. Корінь веретеновидний, довгий. Суцвіття - зонтик, рідке; зубці чашечки колючі, пелюстки білуваті. Плід - еліпсовидна двосім'янка. По ребрах з гострими лусочками. Період цвтіння: липень-вересень.

М. польові ростуть на степових схилах, біля автомобілних доріг, або як бур'ян. Широко поширені в Степу, Лісостепу, на Поліссі трапляється рідко [57]. 
Миколайчики приморські (Eryngium maritimum L.) - багаторічна або дворічна гола рослина. Стебло заввишки 40-70 см, галузиться. Листки шкірясті, світло-зеленого кольору, колючі; прикореневі листки - 3 черешками, верхні листки - стеблообгортні. Корінь досить довгий, маловолокнистий, вузлуватий, синювато-сірого кольору. Суцвіття - кулясті головки з колючими приквітками, пелюстки голубуваті. Плід - двосім'янка кулястої форми, вкрита колючими лусочками. Період цвітіння: червень-липень.

М. приморські ростуть в літоральній смузі Чорного й Азовського морів на піщаних та кам'янистих грунтах [5-7].

Порівняльну характеристику видів року Миколайчики наведено в табл. 1.

Таблиця 1. Порівняльна характеристика видів роду Миколайчики.

\begin{tabular}{|c|c|c|c|c|}
\hline Види & $\begin{array}{l}\text { Висота } \\
\text { стебла }\end{array}$ & $\begin{array}{c}\text { Забарвлення } \\
\text { рослини }\end{array}$ & Листки & Плід \\
\hline М. плоскі & $30-80 \mathrm{~cm}$ & $\begin{array}{l}\text { Рослина } \\
\text { вгорі } \\
\text { синювата }\end{array}$ & $\begin{array}{l}\text { Жорстко- або } \\
\text { тонкошкірясті; нижні } \\
\text { стеблові } \\
\text { глибокороздільні, } \\
\text { короткочерешкові, } \\
\text { овальні або довгасті; } \\
\text { верхні } \\
\begin{array}{l}\text { колючозубчасті, } \\
\text { роздільні }\end{array}\end{array}$ & $\begin{array}{l}\text { Двосім'янка, } \\
\text { стиснуто- } \\
\text { яйцевидна до } 6 \\
\text { мм, вкрита до } \\
\text { середини } \\
\text { вузькими, } \\
\text { загостреними } \\
\text { лусочками }\end{array}$ \\
\hline $\begin{array}{l}\text { М. } \\
\text { польові }\end{array}$ & $30-60 \mathrm{~cm}$ & $\begin{array}{l}\text { Вся рослина } \\
\text { сірувато- } \\
\text { зелена }\end{array}$ & $\begin{array}{l}\text { Жорсткошкірясті; } \\
\text { нижні - черешкові, } \\
\text { верхні - сидячі, } \\
\text { трійчасті, } \\
\text { глибококими } \\
\text { пірчасто-роздільними } \\
\text { сегментами }\end{array}$ & $\begin{array}{l}\text { Двосім'янка, } \\
\text { стиснуто- } \\
\text { обернено- } \\
\text { яйцевидна, до } 5 \\
\text { мм завдовжки, } \\
\text { по ребрах } 3 \\
\text { гострими } \\
\text { довгими } \\
\text { лусочками }\end{array}$ \\
\hline $\begin{array}{l}\text { М. } \\
\text { приморсь } \\
\text { кі }\end{array}$ & $40-70 \mathrm{~cm}$ & $\begin{array}{l}\text { Вся рослина } \\
\text { синювато- } \\
\text { сіра }\end{array}$ & $\begin{array}{l}\text { Шкірясті, } \\
\text { світлозелені; } \\
\text { прикореневі } \\
\text { серцевидно-ниркові; } \\
\text { верхні } \\
\text { стеблообгортні, } \\
\text { роздільні }\end{array}$ & $\begin{array}{l}\text { Двосім’янка } \\
\text { еліпсовидна, } \\
\text { вкрита } \\
\text { лусочками, які } \\
\text { майже колючі } \\
\text { при достиглих } \\
\text { плодах }\end{array}$ \\
\hline
\end{tabular}

Результати, які наведено в табл.1, свідчать, що рослини роду Миколайчики мають відмінні ознаки, що дозволяє з точністю ідентифікувати конкретний вид, 
серед безлічі подібних. Види відрізняються за забарвленням, висотою, будовою листків та плодів. Так м.плоскі зростають висотою до $80 \mathrm{~cm}$, характерним $\epsilon$ синювате забарвленням на верхівці. Листки жорстко- або тонкошкірясті; нижні стеблові листки - короткочерешкові, овальної або довгастої форми; верхні колючозубчасті, 3-5 роздільні. Плід у м.плоских - стиснуто-яйцевидна двосім'янка із загостреними лусочками. М.польові сірувато-зеленого забарвлення, висотою до 60 см; листки жорсткошкірясті; нижні - черешкові, верхні - сидячі, трійчасті, з глибококими пірчасто-роздільними сегментами. Плід - стиснуто-обернено-яйцевидна двосім'янка. М.приморські зростають висотою до 70 см, вся рослина синювато-сірого забарвлення. Листки шкірясті, світлозелені; прикореневі - серцевидно-ниркові; верхні - стеблообгортні, 5роздільні. Плід - еліпсовидна двосім'янка, вкрита лусочками.

Науковці П'ятигорського медико-фармацевтичного інституту (Л.М. Єлисеєва, Е.А. Щербакова, Д.А. Коновалов, М.А. Галкін) вивчали насіннєву та сировинну продуктивність миколайчиків плоских (Табл. 2) [8].

Таблиця 2. Сировинна продуктивність миколайчиків плоских.

\begin{tabular}{|c|c|c|c|}
\hline \multirow{2}{*}{$\begin{array}{c}\text { Рік } \\
\text { вегетації }\end{array}$} & \multirow[t]{2}{*}{ Сировина } & \multicolumn{2}{|c|}{ Продуктивність з однієї рослини } \\
\hline & & Свіжа сировина, Г & $\begin{array}{c}\text { Повітряно-суха } \\
\text { маса, г }\end{array}$ \\
\hline \multirow[t]{2}{*}{1} & корені & 98 & 70 \\
\hline & трава & 105 & 81 \\
\hline \multirow[t]{2}{*}{2} & корені & 115 & 83 \\
\hline & трава & 124 & 98 \\
\hline
\end{tabular}

3 однієї рослини в середньому можна зібрати близько 4 тис. насінин. Маса 1 тис. насіння становить в середньому 2097 г (Табл. 3) [8].

Таблиця 3. Насіннєва продуктивність миколайчиків плоских.

\begin{tabular}{|l|l|l|}
\hline $\begin{array}{l}\text { Кількість насіння } \\
\text { однієї рослини, шт }\end{array}$ & Маса насіння \\
\cline { 2 - 3 } & 3 однієї рослини & \multicolumn{2}{|l|}{$\mathrm{M}^{2}$} \\
\hline 4000 & 7,91 & 39,53 \\
\hline
\end{tabular}

На підставі проведених досліджень встановлено, що миколайчики плоскі можна успішно вводити в культуру. Рекомендується висаджувати рослини на відстані 35-40 см. На 1 м $^{2}$ можна розмістити 4-5 рослин. При цьому з 1 га можна отримати повітряно-сухої надземної маси близько 4,9 т, коренів - 4,2 т, насіння $-3,95$ ц.

Хімічний склад. Трава миколайчиків плоских містить ефірну олію $(0,1$ $0,2 \%)$, сапоніни (0,5\%), таніди (до $1,5 \%)$, яблучну, лимонну, малонову, шавлеву 
та гліколеву кислоти i поліацетиленові сполуки. Хімічний склад коренів близький до трави.

Науковці П'ятигорського медико-фармацевтичного інституту досліджували полісахариди коренів миколайчиків плоских. 3 коренів були виділені водорозчинний полісахаридний комплекс, пектинові речовини, геміцелюлоза А та Б, вихід фракцій становить 14,10\%, 7,3\%, 11,34\%, 2,32\% відповідно [9].

Корені миколайчиків польових містять сапоніни (0,5\%), сахарозу, невелику кількість дубильних речовин, сліди алкалоїдів, близько 0,1 \% ефірної олії, розмаринову, лимонну, малонову, яблучну, оксалову, гліколеву i хлорогенову кислоти, до 160 мг\% вітаміну С. Трава має близький до коренів хімічний склад, але в інших співвідношеннях. Насіння містить до 0,6 \% ефірної олії.

Хімічний склад миколайчиків приморських близький до хімічного складу миколайчиків польових [10].

Фармакологічні властивості. Миколайчики плоскі використовують в народній медицині при лікуванні кашлю, кошлюку, сечостатевих інфекцій, при порушеннях функції нирок, для посилення сечовиділення, усунення каменів та піску з нирок та сечового міхура, для регулювання функції простати. Корінь миколайчиків плоских відомий як спазмолітичний, потогінний, сечогінний, відхаркувальний засіб.

В народній медицині України цю рослину використовують при водянці, статевих розладах, від шлункового й серцевого болю, при безсонні, ревматизмі, зубному болі и карієсі та при бронхіальній астмі. Корені вважались протиотрутою при отруєнні грибами. Зовнішньо миколайчики застосовують для ванн при фітодерматозах і артриті.

Корені миколайчиків польових виявляє сечогінну та спазмолітичну дію. Застосовують його проти коклюшу, при нефритах, водянці, статевій слабості, простатиті, для підвищення апетиту, при запаленні середнього вуха.

В народній медицині корені і траву миколайчиків плоских використовують як ліки при шкірних хворобах, туберкульозі, виразці шлунку та гнійих катарах верхніх, дихальних шляхів, сік з трави або коріння - проти сухот, шкірних хвороб та як сечогінний засіб при літіазі. Зовнішньо препарати 3 миколайчиків використовують для компресів при запаленнях очей і підвищеній вразливості їх на світло [11].

Науковці із Західного університету «Василь Голдій», що в місті Арада (Румунія), досліджували вплив екстрактів миколайчиків плоских та миколайчиків польових на парадонтит у щурів. Ефекти оцінювали гістологічно та за вмістом загальних нітритів та нітратів у сироватці крові, за загальною антиоксидантною реакцію та за індексом окислювального стресу. Результати свідчать про те, що екстракти миколайчиків плоских та миколайчиків польових при експериментальнму пародонтиті щурів проявляли протизапальну активність за рахунок зменшення інфільтрації лейкоцитів та нітрооксидативного стресу [12]. 
Фармакологічні властивості миколайчиків приморських близькі до дії миколайчиків польових. Настій трави та відвар коренів цього виду використовують в народних засобах як протикашльовий, сечогінний, стимулятор та афродизіак.

Дослідники 3 університет Абу Бакра Белкаїд (м. Тлемцен, Алжир) досліджували фармакологічні властивості миколайчиків приморських. Результати цього дослідження свідчать про те, що коріння миколайчиків приморських містить значну кількість фенольних сполук i має значну антиоксидантну, антибактеріальну та протигрибкову активність $[13,14]$.

Висновки. В результаті інформаційного пошуку та аналізу даних літератури, можна стверджувати, що рослини роду Миколайчики здавана використовували в народній медицині. Вони вміщують різноманітні біологічно активні речовини, що зумовлює їх активну терапевтичну дію на організм людини. На території України широко поширені три види миколайчиків, що вказує на можливість їх заготівлі та використанні у медицині. Проведено морфологічний аналіз деяких видів роду Миколайчики, та встановлено основні віддмінні ознаки, що дозволяють ідентифікувати конкретний вид. Види, які зростають на території України відрізняються за висотою та забарвленням надземної частини, за формою листків і плодів. Перспективними $є$ подальші дослідження видів роду Миколайчики для розробки рослинного лікарського засобу на їх основі.

Конфлікт інтересів. Відсутній.

\section{Література.}

1. The Plant List. Royal Botanic Gardens, Kew and Missouri Botanical Garden; 2021. URL: http://www.theplantlist.org/.

2. IPNI. International Plant Names Index., The Royal Botanic Gardens, Kew, Harvard University Herbaria \& Libraries and Australian National Botanic Gardens; 2021. URL: http://www.ipni.org/.

3. BHL. Biodiversity Heritage Library; 2021. URL: https://www.biodiversitylibrary.org/.

4. Royal Botanic Gardens, Kew. Kew; 2021. URL: https://www.kew.org/.

5. Maniuk V. Rodyna selerovykh (Apiaceae) u flori Orilskoho natsionalnoho pryrodnoho parku. Visnyk Dnipropetrovskoho universytetu. Seriia: heolohiia, heohrafiia.. 2016;(24):54-64.

6. Hrodzinskyi A. Likarski roslyny: entsyklopedychnyi dovidnyk. Kyiv: «Ukrainska entsyklopediia» im. M. P. Bazhana; 1992. 544 s. — ISBN 5-88500055-7.

7. Shcherbakova E. Morfolohycheskye y anatomycheskye dyahnostycheskye pryznaky syneholovnyka kavkazskoho y syneholovnyka ploskolystnoho. Mezhdunarodnyi nauchno-yssledovatelskyi zhurnal. 2016;(7):129-31.

8. Elyseeva L, Shcherbakova E, Konovalov D, Halkyn M. Syirevaia y semennaia produktyvnost syneholovnyka ploskolystnoho semeistva seldereinye (apiaceae). Farmatsyia y farmakolohyia. 2015;(1):14-6. 
9. Shcherbakova E. Yzuchenye polysakharydnoho kompleksa $\mathrm{v}$ korniakh nekotorykh vydov syneholovnyka, yntrodutsyrovannykh $\mathrm{v}$ uslovyiakh predkavkazia. Sbornyk nauchnykh trudov HNBS. 2018;(146):214-8.

10.Nebija F, Stefkov G, Karapandzova M. Chemical characterization and antioxidant activity of Eryngium campestre L., Apiaceae from Kosovo. Macedonian pharmaceutical bulletin. 2009;(55):23-32.

11.Arykbaeva A, Ustenova H, Sharypov K, Hemedzhyeva N. Perspektyvy yspolzovanyia lekarstvennoho rastenyia - syneholovnyka ploskolystnoho (Eryngium planum L.). Vestnyk KazNMU. 2018;(20):89.

12.Conea S, Pârvu A, Taulescu M, Vlase L. Effects of Eryngium planum and Eryngium campestre extracts on ligatureinduced rat periodontitis Article. Digest Journal of Nanomaterials and Biostructures. 2015;(10):693-704.

13. Wahiba K, Faiza I, Chahrazed B, Fawzia A. Eryngium maritimum: A Rich Medicinal Plant of Polyphenols and Flavonoids Compounds with Antioxidant, Antibacterial and Antifungal Activities. Current Research Journal of Biological Sciences. 2012;(4):437-43.

14.POWO. Plants of the World Online. Kew Science; 2021. URL: http://www.plantsoftheworldonline.org/. 